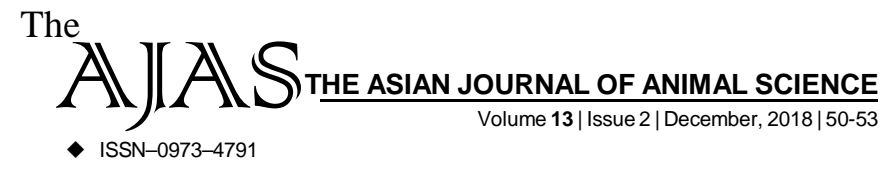

\title{
Histological and histochemical studies of dermis in crossbreed cattle
}

\section{P.J. Kapadnis and P.N.Thakur}

Author for Corresponding -

\section{P.N. Thakur}

Department of Veterinary

Anatomy and Histology

College of Veterinary and Animal

Sciences, Parbhani (M.S.)

India
ABSTRACT...... The skin of crossbreed cow (Deoni x HF, $\mathrm{F}_{1}$ generation) histologiocally showed, dermis The dermis was consisted to dense irregular connective tissues with a feltwork of collagen, elastic and reticular fibres along with the sweat gland, sebaceous gland, hair follicles, ararector pilli muscles, blood vessels, lymph vessels, nerves and connective tissue cells i.e. fibroblast. It was divided into two layers as a superficial papillary layer and deep reticular layer without a clear demarcation.

KEY WORDS...... Histology, Histochemistry, Dermis, Crossbreed cattle

HOW TO CITE THIS ARTICLE - Kapadnis, P.J. and Thakur, P.N. (2018). Histological and histochemical studies of dermis in crossbreed cattle. Asian J. Animal Sci., 13(2): 50-53. DOI : 10.15740/HAS/TAJAS/13.2/50-53. Copyright@2018:HindAgri-Horticultural Society.

ARTICLE CHRONICLE - Received : 27.08.2018; Revised : 03.11.2018; Accepted : 14.11.2018 